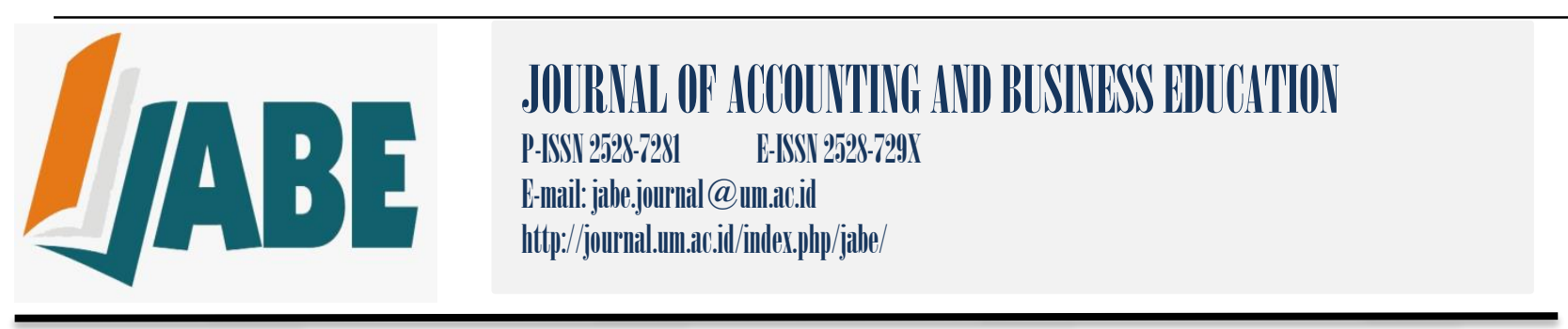

\title{
Understanding Factors Affecting Local Administration Reform on Accrual- Based Financial Statements
}

\author{
Haryono Sukamdaru \\ Bambang subroto \\ Endang Mardiati \\ Brawijaya University \\ sukamdaru@gmail.com
}

\begin{abstract}
This study is set out to analyze the understanding of local government officials on the accrualbased financial statements. The analyses are performed on the effects of training, education, working experience, and the quality of information technology to comprehending accrual-based financial statements. Furthermore, the data are collected using questionnaires, and distributed to all officials responsible for financial statements and financial administration officials in all working units (SKPD) in Probolinggo Municipality, and the used samples are 57 respondents. Data analysis method is double regression. The result of this study indicates that the training and working experience positively influences on the comprehension of accrual-based financial statements. The quality of education and information technology do not bring a pass to the understanding of accrual-based financial statements.
\end{abstract}

Keywords : Accrual-based financial statements understanding, education, information technology quality, training, work experience

\section{INTRODUCTION}

In Indonesia, New Public Management in financial reform field is got under way over the enactment of state finance subject law package No 17 Year 2003 as to State Finance, Law No. 1 Year 2004 in subject of State Treasury and Law No. 15 Year 2004 on the Management Inspection and State Finance Liabilities. One of the requisites in Law No.17 Year 2003 as to State Finance is to oblige the presence of Governance Accounting Standard (SAP) as the fundament of creating financial statement for government institutions.

Law No. 17 Year 2003 in subject of State Finance calls for the administration to enact acrual-based accouting with the latest due f 5 years since the enactment of that law. As a 
guidance, Government Regulation (GR) No. 71 Year 2010 on the Governance Accounting Standard to substitute Government Regulation No. 24 Year 2005 is issued. In GR No. 71 Year 2010 the enactment due (full acrual) was held off up to 2014.

Meanwhile, the abovementioned opinion on the enactment of acrual-based accounting in Probolinggo town was Qualified. The inspection result report of Probolinggo town in 2015 explicated several opinions bringing about Qualified opinion was the weak intern control system and the law compliance finding. In addition, Madura Newspaper (2016) explained that the reporting system alteration from cash-based to acrual-base had become the issue making Probolinggo Town Government get rated Qualified. This indicated that there ought to be understanding from local officers of Probolinggo town in relation to the acrual-based financial statement system.

A few of researches in Indonesia in subject of acrual-based financial report is carried through by Mulyana (2009) argued that acrual-based financial report could provide government performance review to assess the effectiveness and the efficience in managing resources. The comprehension of acrual-based government accounting standard must be supported over highperforming human resources. Competent human resources take big part in determining the development and the advancement of organization. Human resource indicator can be assessed from the eduaction level, in regard with Cahyadi (2009) qualified human resources with high academic capacity can assist in completing tasks particularly whilst making regional financial report. Malik (2010) argued that training had impact on the generated information which was qualified accounting information presentation in concert with the objective of the organization. Work experience as human resource assessment instrument is stated in the study of Purnamasari (2005) that employees with high work experince would get the edges in detecting errors whilst presenting financial report.

The study on the comprehension as well as the success of acrual-based system implementation has been prevalently undertaken and has generated various results. The studies showing the results that of human resource can be measured through their participations in training, work experience, and academic background in comprehension as well as the success of acrual-based implementation are as follows: Windels \& Christiaens (2008), Halen \& Astuti (2013), Lelono (2014), and Supra (2016). The opposite resuts are found in the studies of Rizkianci (2016) dan Parananda (2015). 
Halen \& Astuti (2013) studies provided results that training level, comprehension, and assistance affected on the acrual-based implementation in the financial management of Jember regency carried out in 19 SKPD institutions of Jember Regency. Windels \& Christiaens (2008) provided studies results that of executive academic levels and staff had a positive impact on the rate of reform adoption. Supra (2016) conducted a study on SKPD Musi Banyusin with a sample of 123 respondents explaining that the level of education, training and quality of information have a positive influence on the application of accrual-based SAP. Lelono (2014) explained that the official environment of Salatiga City government by drawing a sample of 42 respondents indicated that the different comprehension of the accrual-based financial statements preparation has different levels in views of education, training followed and work experience. Different research results obtained from Rizkianci's (2016) study provided results that training, human resources and organizational commitment had no effect in the readiness of SAP accrual-based implementation in Riau Isle province, but information technology had a strong influence on the accrual-based SAP implementation. Parananda (2015) stated that education and employment rates did not affect the application of local government accounting systems in Ngawi and Pacitan districts.

This research is also a development of Supra research (2016) by adding work experience variables. The reason researchers add to the variable work experience is that should someone have more work experience on the task that he/she focuses then the more skilled and perfect mindset and act in achieving the goals set (Puspaningsih, 2004). In addition, the decline of Unqualified opinion to Qualified Opinion since the implementation of accrual basis in Probolinggo City makes the researcher wants to know the supporting factor on the accrual basis of financial report.

\section{LITERATURE REVIEW AND HYPOTHESES}

\section{Understanding Accrual-based Accounting}

Understanding can be interpreted as an attempt to interpret and express the meaning of something on symbols, these symbols can be said to derive from the meaning of a person or something, so that meaning symbol means effort to expose and capture something contained in that symbol (Raharjo, 2008). 
According to a complete dictionary of Indonesian (2005) understanding is something that is understood and understood correctly. According to Suharsimi (2009) states that comprehension is how one differentiates, defends, estimates, broadens, explains, summarizes, gives examples, generalizes, estimates, and rewrites. Each organization or entity has guidelines in carrying out its activities, one of which is in the preparation of financial statements. In the government there is a Government Regulation on Government Accounting Standards that should be understood and implemented by every government entity. the local governments, accordingly, can present accountable financial statements and can attain Unqualified opinion.

\section{Learning Theory}

Learning is an event can happen at any time. Learning means a change in the attitude of a relatively fixed behavior that occurs all the time (Weiss, 1990). Learning is not only done and obtained from the school environment or from the educational environment, but learning can happen at any time. There are three components involved in the definition of learning, including: (a) learning that involves change; (b) changes must be fixed; and (c) need experience, which can be directly through training or observation, or acquired indirectly.

Selanno (2014) which explains that learning can lead to change. Organizations have a learning point of view that learning can be good and can have adverse impacts, as some people learn less good behavior and learn good behavior. Changes must be relatively stable, this may illustrate that temporary changes would relatively fail. Hence, learning that eliminates a change will impact weakness. Third, interpreting focuses on behavior, learning proceeds in the course of action, direct change is explained when learning occurs with behavioral changes in individuals.

\section{New Public Management (NPM)}

The NPM concept assumes that private sector commercial business practices are better than the public sector, so in order to improve the performance of the public sector it is necessary to adopt some of the techniques and practices of private sector management in the public sector (Mardiasmo, 2002). With management changes in the public sector it causes a change in the public sector accounting system. changes need to be made because cash-based accounting systems are deemed unsatisfactory, especially in the lack of presentation of the financial picture 
in providing useful and adequate management information for planning and performance processes (Cohen, Kaimenaki, \& Zorgios, 2007).

According to Christiaens et al. (2001: 2003) governance accounting reforms were the first steps in government reform so that it could be taken a view as an important condition as a precondition for successful government reforms under the frequency of NPM transformation, such as managerial and organizational reform. Therefore, effective and successful accounting reforms play an important role in the success of NPM techniques and practices in public organizations. Without a sufficient and successful implementation, all the hopes, advantages, and objectives of reform will be lost because the fact that there is a new accounting system will not be able to provide the relevant and accurate managerial and financial information to support it (Christiaens \& Peteghem, 2007).

\section{Accrual Accounting System}

The accrual accounting system is a method of recording transactions on events and the recognition of costs (expenses) based on the period of the event occurences (Guthrie, 1998). Accrual-based accounting is an accounting basis in which economic transaction is recorded, recognized and presented in the format of financial statements on the moment of the transaction and regardless of the time of cash receipt or payment. Recording is called in accordance with the time of the flow of resources, so that information can be available comprehensively (Simanjuntak, 2010). In accrual-based accounting, figures are considered more informative for leaders in the public sector for resource allocation and decision-making and accountability.

Some countries that adopt accrual accounting system including Australia by way of responsibilities decentralization at the lowest level in government organizations, accountable manager placements, the concept of citizens as customers (Guthrie, 1998). The Italian state also applies changes from traditional cash-based and bonds accountings to accrual accounting, bringing a pass to wider spectrum of transparency in public finance, resource us, and a focus on various cases of financial scandals and corruption and increased accountability (Caccia \& Steccolini, 2006). Thus, public-sector-based accrual accounting can apply a full cost system for all activities, realize efficiency, allocate resources in accordance with the targets and can improve performance. 


\section{Accrual-Based Accountung in Indonesia}

Government accounting reform in Indonesia begins with the issuance of Law No. 17 of 2003 on state finances and Law No. 15 of 2004 on audits of state financial management and accountability. With the advent of these two laws, the requisite of the government accounting standard to prepare and audit the financial statements of government agencies by BPK. Without a standard financial report, BPK can not provide an audit opinion. Form of accountability of APBN / APBD in the form of financial statements that must be prepared in accordance with Government Accounting Standards.

Government accounting standard is made by independent government accounting standards committees. The preparation of accrual-based SAP is carried out by the KSAP through a standard drafting process. The compilation of PSAP is based on the Conceptual Framework of Government Accounting, which is used as the basic concept of development and development of Government Accounting Standards, and is used as a reference for Government Accounting Standards Committee, auditors, financial reporters, and users of financial statements used in addressing issues not yet regulated in Statement Government Accounting Standards.

Determination of government regulation No. 24 of 2005 on Standard Accounting Government is a mandate of state finance laws. Government Regulation No. 24 of 2005 is used for cash basis for recognition of revenue, expense and financing transactions. As for the assets, liabilities and equity of funds using the accrual basis. Recognition, measurement of accrual based income and expenditure pursuant to Article 36 paragraph (1) of Law Number 17 Year 2003 shall be implemented no later than 5 (five) years. Therefore, Government Regulation No. 24 of 2005 is replaced by Government Regulation no. 71 Year 2010 which includes Accrual Based SAP and SAP Based Cash towards Accruals.

In addition, the application of Cash-Based to Accrual SAP is brought off in regard with the period in assent with what is contained in Attachment II of the Regulation, which is up to the end of 2014. Furthermore, every reporting entity, either central government or local government, is called for implementing Accrual-Based SAP. Although the reporting entity is temporarily allowed to apply Cash-based SAP towards Accruals, the reporting entity is expected to implement Accrual Based SAP any time now.

The implementation of accrual-based accounting in Indonesia is expected to serve greater benefits for the government, and for the community as users of financial statements. Benefits for 
the government, among others, to provide more transparent information about government costs and improve the quality of decision-making within the government by using more extensive information, not just cash-based information benefitting the community as users of the report (Simanjuntak, 2010).

\section{Training on The Understanding of Accrual-Based Financial Report}

Coaching is delineated as a skill in grasping a particular skill by means of completing a ceratin task so that an objective can be attained over various modes which are seminar participation, simponsium as well as training workshops (Cahyadi, 2009). Alijarde (1997) argued that adequate training is required to address the changes from accounting systems implemented by the government from cash-based systems to accruals. In this case, training should be able to provide mechanisms for local government apparatus to understand, accept, and feel conformed to the concepts of NPM instruments such as accrual based financial statements (Cavalluzzo \& Ittner, 2004).

Thereby, financial report training carried continuously will add the understanding of government apparatus on the accrual-based financial report. Learning theoretical account addresses that learning is not only manifested from academic surrounding but also from the training that is frequently attended. Krumwiede (1998) explained that adequate training brought a pass positively on the success of accounting system deduction by way of providing an understanding as to how to design, use and implement accrual accounting system. The previous research revealed that the training positively influenced the application of local government financial statements on an accrual basis, research on Halen \& Astuti (2013), Kusuma (2013), Lelono (2014), Supra (2016), and Usman, Sunandar, \& Farida (2016). In view of the explanations, the hypothesis in this study are:

$\mathrm{H} 1=$ There is a positive influence of training on the understanding of accrual basis financial statements.

\section{Education over the Understanding of Accrual-Based Financial Statement.}

A public policy implementation in practice called for adequate human resource capacity in matters of quantity and expertise (competence, experience, and adequate information), in addition to organizational capacity building (Insani, 2009). In assent with Nazier (2009) 76.77\% 
of financial management units owned by the central and local government were inhabited by employees who had no accounting education background as a form of required basic knowledge for financial management.

In addition, it was also found that the regional apparatus had difficulties in delivering accountable, transparent, timely, and prepared government financial statements followed by SAP. This was owing to the lack of expert staffs in implementing and budgeting accountability, eminently accounting expertises (Zetra, 2009). Education as a planned conscious effort to develop the knowledge and competence possessed by goal-oriented individuals. Adequate education of an individual would provide deep insight (Mulyawati, 2008). Education affected the implementation of accrual-based financial statements, as evidenced by Supra (2016) stating the compatibility of education diploma and background in accordance with the field of work affected the application of accrual-based accounting. In line with research Wiraputra (2014) which proved that education gave rise to the presentation and preparation of local government financial statements. With regards to the explanations, the hypothesis in this study are:

$\mathrm{H} 2=$ There is a positive effect of education on the understanding of accrual basis financial statements

\section{Work Experience on the understanding of accrual basis financial statements}

Organizations with frequent experience in applying accrual accounting are expected to better achieve a better level of accounting understanding (Christiaens \& Vanhee, 2001). A work unit or organization with experience running and implementing accrual basis accounting is expected to achieve a better level of understanding in the adoption and implementation of the new system (Kusuma, 2013).

Reviewing the learning theory, an individual who is accustomed in bringing off his work will add to his work experience. Experience is depicted as the number of work variations that one performs and the more experience then enables performance improvement (Simanjuntak, 2005). In this research, experience is associated with the many variations of work and a certain period of time by the local government apparatus in making financial reports on local government scope.

A few of relevant studies in relation to the effect of work experience on the accrual-based financial statement understanding brought off by Lelono (2014) and Pristiani \& Mahmud (2016) 
expressed that work experience had positive effect on the understanding of accrual-based financial statement. In view of that explication, accordingly, the hypotheses are as follows:

$\mathrm{H} 3$ = There is a positive effect of Work Experience to the accrual-based financial statement understanding.

\section{Information Technology Qualities Towards the Understanding of Accrual-Based Financial Statement.}

Organizations with more modern information technology quality made it possible to run and implement accrual-based accounting system rather than work units with less sophisticated information systems (Krumwiede, 1998). Information technology was required to support and facilitate in carrying out and introducing accrual accounting in public sector. Hence, the high quality contained in the information system of the work unit should be considered as one of the substantial conditions in successful implementation of accrual-based accounting adopted from NPM (Ouda, 2008).

The quality of information technology in this study was set out as a technology quality containing information in the preparation of financial statements so as to present reliable and qualified local government financial reports. According to Suyanto (2005) information technology was the whole form of technology used in creating, storing, using and changing information in all forms. Information technology included from software, hardware and also brainware, with a combination of three that supported each other would provide a useful information technology for the recipient of information. From the explanation, the hypothesis of this research are:

$\mathrm{H} 4=$ There is a positive influence of information technology quality on the understanding of accrual-based financial statements

\section{METHODS}

The used approach for this study is quantitative explanatory research, a study which explained causal-relation phenomenon between variables through formulated hypothesis test (Kuncoro, 2007). This study inclines to explicate the incluences of independents variables such as training, education, work experience, and information technology quality on dependent variables like the understanding of accrual-based financial statement. 
The population of this study is the entire SKPD Probolingo Town with 40 SKPD comprising 1 Inspectorates, 7 Institutions, 14 Agencies, 2 Offices, 2 Secretariates, 8 Units, 1 Regional Hospital, and 5 Sub-Districts. Analysis Unit of this study is all of SKPD heads and Financial Administration Officer in Probolinggo Municipal Government is 80 people. The reason researchers to select SKPD head is due to the fact that the ones responsible for financial reports and financial administration officials are officials who prepare financial statements.

This study uses all members of the population called the census. The use of this method applies if the members of the population are relatively small (easy to reach). This research by looking at the total population of 80 respondents, the researcher uses census method, the use of this method is expected to give result which close to real value and minimize the deviation on population value (Usman \& Akbar, 2008).

The data source of this study using primary data (primary data), obtained directly from the original source or respondent (not through intermediary media). The used primary data in this research is the questionnaire answers from research respondents.

This study tested the proposed hypothesis by way of SPSS assistance. The technique of analysis in this study uses multiple regression analysis to test the hypothesis, because in this study there are 4 independent variables and 1 dependent variable. So the equations used in this study are:

$$
Y=\alpha+\beta_{1} X_{1}+\beta_{2} X_{2}+\beta_{3} X_{3}+\beta_{4} X_{4}+e
$$

Information :

$\mathrm{Y}=$ The Understanding of accrual financial statements

$\mathrm{X} 1=$ Training

$\mathrm{X} 2=$ Education

$\mathrm{X} 3=$ Work Experience

$\mathrm{X} 4$ = Information Technology Qualities

$\alpha=$ constants

$\beta \mathrm{i}=\mathrm{Xi}$ variables regression coefficient

$\mathrm{e}=$ error

\section{RESULTS}

The used data in this study is primary data directly obtained from the respondents over providing questionnaires to all respondents. The number of work units in Probolinggo City is 40 
(forty). The distribution of questionnaires and the return of questionnaire data takesthe whole month of December.

Some general information about the characteristics of respondents used in this study based on sex, level of education, age, employment, position and rate of return questionnaire. Here is presented in table 1.

Tabel 1. Respondents Characteristics dan Response Rate Level

\begin{tabular}{|c|c|c|c|}
\hline Group & & Frequency & Percentage \\
\hline \multirow[t]{2}{*}{ Sex } & Male & 31 People & $54,38 \%$ \\
\hline & Female & 26 People & $45,62 \%$ \\
\hline \multirow[t]{2}{*}{ Education Level } & Undergraduate & 17 People & $29,82 \%$ \\
\hline & Graduate & 40 People & $70,18 \%$ \\
\hline \multirow[t]{3}{*}{ Age } & 31- 40 Years & 21 People & $36,84 \%$ \\
\hline & 41- 50 Years & 12 People & $21,05 \%$ \\
\hline & > 50 Year & 24 People & $42,11 \%$ \\
\hline \multirow[t]{4}{*}{ Work Period } & $5-10$ Years & 11 People & $19,30 \%$ \\
\hline & $10-20$ Years & 14 People & $24,56 \%$ \\
\hline & $20-30$ Years & 22 People & $38,60 \%$ \\
\hline & $30-40$ Years & 10 People & $17,54 \%$ \\
\hline \multirow[t]{2}{*}{ Job Title } & Agency Head & 17 People & $29,82 \%$ \\
\hline & PPK & 40 People & $70,18 \%$ \\
\hline $\begin{array}{l}\text { Quetionnaire Return Rate } \\
\text { Distributed }=80 \\
\text { Unreturned }=20 \\
\text { Returned }=60 \\
\text { Unqualified }=3 \\
\text { Processed }=57 \\
\text { Response Rate }=71,25 \%\end{array}$ & & & \\
\hline
\end{tabular}

\section{The Results of Data Analysis Techniques}

Validity Test and Reliability Test

Table 2. The Result of Validity and Reliability Training

\begin{tabular}{cccc}
\hline Questions/Item & \multicolumn{2}{c}{ Training } \\
\cline { 2 - 4 } & Anti Image Value & Information & $\begin{array}{c}\text { Croncbach } \\
\text { Alpha Value }\end{array}$ \\
X1.1 & 0,681 & Valid & \\
\hline
\end{tabular}




\begin{tabular}{lllll}
\hline $\mathrm{X} 1.2$ & 0,771 & Valid & 0,790 & Reliable \\
$\mathrm{X} 1.3$ & 0,677 & Valid & & \\
$\mathrm{X} 1.4$ & 0,647 & Valid & & \\
\hline
\end{tabular}

Based on table 2, it shows that validity test results display that all items are valid because it has more than 0.5 value. Cronbach Alpha value is more than 0.6, which means that the reliability requirement is fulfilled. Thus, it can be concluded that all items that measure the training variables can meet the requirements of validity and reliablitas so that further analysis can be undertaken.

\section{Work Experience}

Table 2. Work Experience Validity and Reliability Test Result

\begin{tabular}{ccccc}
\hline Questions/Items & \multicolumn{4}{c}{ Work Experience } \\
\cline { 2 - 5 } & $\begin{array}{c}\text { Anti Image } \\
\text { Value }\end{array}$ & Information & $\begin{array}{c}\text { Croncbach } \\
\text { Alpha Value }\end{array}$ & Information \\
X3.1 & 0,608 & Valid & $\mathbf{0 , 6 6 1}$ & Reliable \\
$\mathbf{X 3 . 2}$ & 0,436 & Invalid & & \\
$\mathbf{X 3 . 3}$ & 0,609 & Valid & \\
\hline
\end{tabular}

Based on table 4, shows that the validity of experience test results indicate one item is $\mathrm{X} 2.2$ is invalid because it is less than 0.5 so the indicator is omitted. Cronbach Alpha value is more than 0.6 which means the reliability requirements are met. The following test results of validity and reliability upon X3.2 are removed.

\section{Information Technology Qualities}

Table 3. Technology Information Qualities Validity and Reliability Test Results

\begin{tabular}{|c|c|c|c|c|}
\hline \multirow{3}{*}{$\begin{array}{l}\text { Questions/It } \\
\text { ems }\end{array}$} & \multicolumn{4}{|c|}{ Information Technology Qualities } \\
\hline & \multicolumn{2}{|c|}{ Validity } & \multicolumn{2}{|c|}{ Reliability } \\
\hline & $\begin{array}{l}\text { Anti Image } \\
\text { Value }\end{array}$ & Information & $\begin{array}{l}\text { Croncbach } \\
\text { Alpha Value }\end{array}$ & Information \\
\hline X4.1 & 0,336 & Invalid & & \\
\hline
\end{tabular}




\begin{tabular}{|c|c|c|c|c|}
\hline $\mathrm{X} 4.2$ & 0,641 & valid & 0,842 & Reliable \\
\hline X4.3 & 0,573 & valid & & \\
\hline X4.4 & 0,603 & valid & & \\
\hline X4.5 & 0,699 & valid & & \\
\hline X4.6 & 0,673 & valid & & \\
\hline X4.7 & 0,837 & valid & & \\
\hline X4.8 & 0,723 & valid & & \\
\hline
\end{tabular}

With regard to table 5 , shows that the results of experience validity test displays one invalid question X4.1 because it is less than 0.5 so it is removed. Cronbach Alpha Value is more than 0.6 which means the reliability requirements are met. The following test results of validity and reliability upon $\mathrm{X} 4.1$ are removed.

Table 6. The Result of Validity and Reliability Test on the Understanding of Acrual-Based Financial Statement

\begin{tabular}{|c|c|c|c|c|}
\hline \multirow[t]{3}{*}{ Questions/Items } & \multicolumn{4}{|c|}{ Acrrual-Based Financial Statement Understanding } \\
\hline & \multicolumn{2}{|c|}{ Validity } & \multicolumn{2}{|c|}{ Reliability } \\
\hline & $\begin{array}{c}\text { Anti Image } \\
\text { Value }\end{array}$ & Information & $\begin{array}{l}\text { Croncbach } \\
\text { Alpha Value }\end{array}$ & Information \\
\hline Y.1 & 0,873 & Valid & \multirow{10}{*}{$\mathbf{0 , 8 7 8}$} & \multirow{10}{*}{ Reliable } \\
\hline Y.2 & 0,784 & Valid & & \\
\hline Y.3 & 0,798 & Valid & & \\
\hline Y.4 & 0,903 & Valid & & \\
\hline Y.5 & 0,811 & Valid & & \\
\hline Y.6 & 0,873 & Valid & & \\
\hline Y.7 & 0,843 & Valid & & \\
\hline Y.8 & 0,809 & Valid & & \\
\hline Y.9 & 0,816 & Valid & & \\
\hline Y.10 & 0,782 & Valid & & \\
\hline
\end{tabular}

Based on table 6, shows that the result of validity test of accrual basis financial statements shows thar all items are valid as it has more than 0,05 value. Cronbach Alpha value is more than 0.6, which means that the reliability requirement is met. Accordingly, it can be concluded that all items that measure the variable understanding of accrual-based financial statements can meet the requirements of validity and reliability so that further analysis can be done. 


\section{The Results of Double Regression Analysis}

The magnitude of the influence of independent variables (training, education, work experience, and quality of information technology with the dependent variable (understanding of accrual basis financial statements) can be seen from the following table:

Table 7. Regression Test Result

\begin{tabular}{|c|c|c|c|c|}
\hline Variable & Beta Coeficients & $\mathrm{T}$ & Sig. & Conclusion \\
\hline Training (X1) & 1,034 & 1,837 & 0,032 & accepted \\
\hline Education(X2) & $-0,074$ & $-0,0368$ & 0,714 & declined \\
\hline $\begin{array}{l}\text { Work } \\
\text { Experience } \\
\text { (X3) }\end{array}$ & 1,385 & 1,769 & 0,022 & accepted \\
\hline $\begin{array}{l}\text { Information } \\
\text { Technology } \\
\text { Quality (X4) }\end{array}$ & 0,022 & 0,071 & 0,943 & declined \\
\hline Constants & 10,025 & & & \\
\hline R Square $\left(\mathbf{R}^{2}\right)$ & 0,233 & & & \\
\hline $\mathbf{R}$ & 0,482 & & & \\
\hline $\mathbf{F}$ & 3,943 & & & \\
\hline Sig. F & 0,007 & & & \\
\hline
\end{tabular}

In view of the double regression analysis, regression equation can be formulated

$$
\mathrm{Y}=10,025+1,034 \mathrm{X1}-0,074 \mathrm{X} 2+1,385 \mathrm{X3}+0,022 \mathrm{X} 4+\mathrm{e}
$$

\section{The Result of Classic Assumption Test Requirements}

\section{Normality Test}
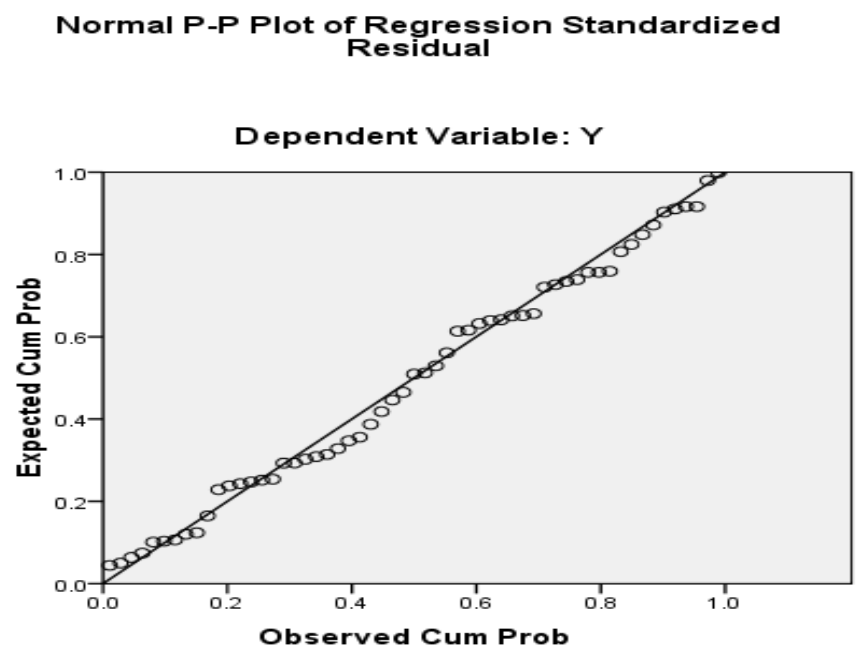

Figure 1 Normality Test Result 
In view of figure 1 , the regression model has a normal distribution. This is owing to the data spreads along the line of normality.

\section{Multicollinearity Test}

The multicollinearity test is used to show the linear relationship between the independent variables in the regression model. Multicollineraity can be known by the VIF (Varians Inflation Factor) test. The multicolinearity-free regression model has a VIF strength value of less than 10 (Ghozali, 2011). The test results show that VIF value of all independent variables is below 10. Thus, there is no multicollinearity problem. The result of multicollinearity assumption can be checked in table 8 below:

\section{Table 8 Multicollinearity Test Result}

\begin{tabular}{cc}
\hline Variable & VIF \\
\hline $\mathbf{X 1}$ & 1,927 \\
$\mathbf{X 2}$ & 1,027 \\
$\mathbf{X 3}$ & 1,298 \\
$\mathbf{X 4}$ & 1,613 \\
\hline
\end{tabular}

\section{HeteroscedasticityTest}

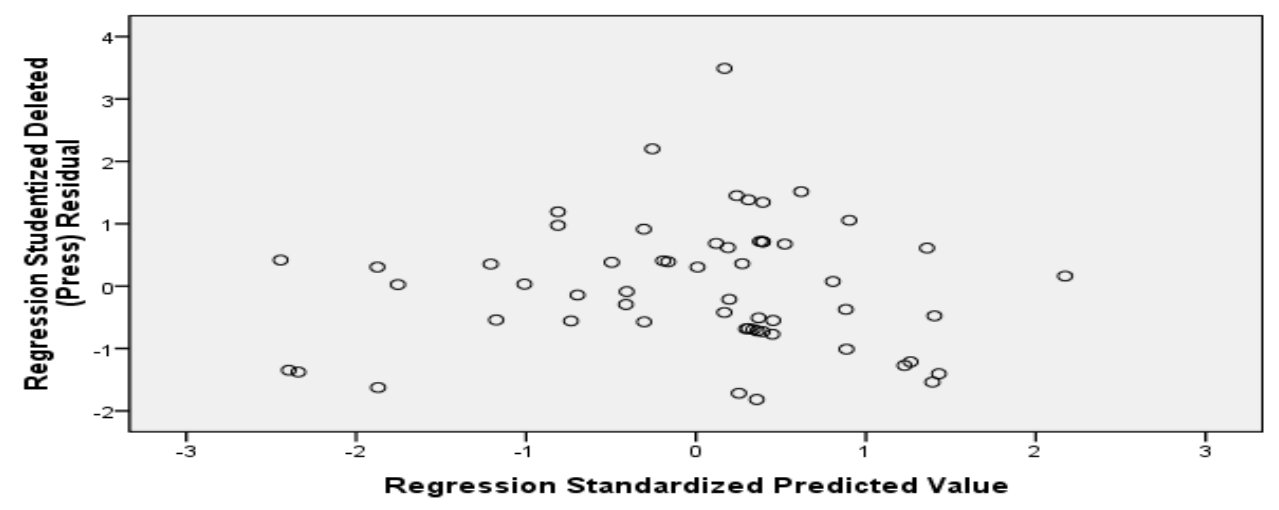

Figure 1. Heteroscedasticity Test Result

The picture explains that there are no symptoms of heteroscedascity over viewing the form patterns that disseminate either up or down in assent with the provision that there are no symptoms of heteroscedascity when the pattern spreads. 


\section{Autocorrelation Tets}

The general test used to determine the presence of autocorrelation is using Durbin Watson (DW) statistic test. This DW value generates the value of D arithmetic (d) and the DW value of the table ( $d L$ and $d U$ ). Provided that if in the value of $d U<d<4-d U$, there is no autocorrelation problem. The result of data analysis got DW value equal to 1,557 while from Durbin Watson table with criterion value of $\alpha=5 \%, \mathrm{n}=57$ and (K-2) 2 is obtained in 1,5004 value and $\mathrm{dU}$ equal to 1,642 . Thus, $\mathrm{dL}<\mathrm{D}<\mathrm{dU}$ or $1,5004<1,557<1,642$ this proves that there is no autocorrelation.

\section{Hypothesis testing}

The results of data analysis listed in table 7 got the value of coefficient of determination (R2) of 0.482 this shows that the percentage contribution of simultaneous influence of independent variables to the dependent variable of $48.2 \%$, while the remaining of $51.8 \%$ influenced by other variables which was not included in this study.

Based on the result of analysis of table 7 it is known that $t$ value is greater than 1.64. The level of significance is less than 0.05 , which means that training influences the understanding of accrual basis financial statements. Coefficient beta positive sign signifies that the training has a positive effect on accrual basis financial statements. Thus, it can be inferred that the more training that is followed, the bigger the probablity on the understanding of the financial statements will increase. Based on the results of the analysis of table 7 it is known that the value of $t$ is smaller than 1.64. The level of significance is less than 0.05 , which means that education does not affect the accrual based financial statements. The beta coefficient marked negative means education does not have a positive effect on the understanding of accrual based financial statements. Thus, it can be inferred that the education background of the apparatus does not improve the understanding of accrual-based financial statements.

From the result of analysis of table 7 it is uderstood that $t$ value is greater than 1.64. The level of significance is less than 0.05 which means that work experience affects the understanding of accrual basis financial statements. The beta coefficient marked positive means that work experience has a positive effect on the understanding of accrual basis financial statements. Accordingly, it can be concluded that the more experienced apparatus in the field of work it will have a positive effect on the understanding of accrual-based financial statements. In 
assent with the analysis result of table 7 it is known that the value of $t$ is smaller than 1.64. The level of significance is greater than 0.05 which means the quality of information technology does not affect the understanding of accrual basis financial statements. Thus it can be concluded that the quality of information technology has no effect on the accrual-based financial statements.

\section{DISCUSSION}

\section{The effect of training on the understanding of accrual basis financial statements}

The results showed that the training had a positive effect on the understanding of accrual based financial statements. This indicates that the training provided to the responsible officers of financial statements and financial administration officials can improve their understanding of accrual basis financial statements.

The results of this study are in line with the study carried out by Kusuma (2013), Halen \& Astuti (2013), Supra (2016), and Jantong (2016) arguing that the training had a positive accounts on the successful implementation of accrual-based accounting standards. The results of this study indicate that the more frequent responsibility and financial administration to follow the preparation of financial report training, the better it can provide benefits and slacken errors in the preparation of accrual-based financial statements. This means that the apparatus that often participate in the preparation of financial reporting training can improve the understanding of accrual based financial statements. The results of this study, thereby, refine the learning theory that the more frequent the training that is participated, the better the chance to improve skills and abilities.

\section{The influence of education on the understanding of accrual basis financial statements}

The results of this study indicate that education does not affect the understanding of accrual-based financial statements. This finding is in concert with the results of research by Rizkianci (2016) and Parananda (2015). In their researches, they proved that education had no influence on the local government accounting system. This was because of the ability to analyze and educational background the apparatus possessed are not sufficient to overcome the problems in accrual-based regional financial statements. That means the ability to analyze and educational background of the apparatus can not really count in the understanding of accrual-based financial statements. 
Learning theory explains that learning traits can be obtained from education in school. In relation to this research, the attitudes held by the financial person in charge in Probolinggo Town assume that the financial statements are the responsibility of the financial administration officials in each unit of the regional apparatus (SKPD). Eriva, Islahuddin, \& Darwanis (2013) in the study also explained that higher levels of education would occupy high positions so that their job responsibilities were only on the endorsement of results, but not directly immersed in the settlement of local financial statements. The findings in this study differ from Windes and Cristian (2008), Hallen and Astuti (2013), and Supra (2016) studies evidencing that education had positive significances on the accrual-based SAP application.

\section{The effect of work experience on the understanding of accrual basis financial statements}

The results of this study indicate that work experience has a positive effect on the understanding of accrual basis financial statements. This shows the more apparatus pursue field work can add to work experience and affect the understanding of accrual-based financial statements.

The results of research are in line with the results of Lelono (2014) and Pristiani \& Mahmud (2016) studies which stated that work experience has a positive influence on the understanding of accrual basis financial statements. This indicates that work experience can add to the apparatus understanding of accrual based financial statements. Judging from the theory of learning, an individual who is accustomed in carrying out his work will add to his work experience. Experience is defined as the number of work variations a person performs and the more experience then enables performance improvement (Simanjuntak, 2005).

\section{The effect of information technology quality on the understanding of accrual basis financial statements}

Organizations with more modern information technology quality make it possible to run and implement accrual-based accounting system rather than work units with less sophisticated information systems (Krumwiede, 1998). Information technology is required to support and facilitate in carrying out and introducing accrual accounting in the public sector. Thus, the high quality contained in the information system of the work unit should be considered as one of the important conditions in the successful implementation of accrual-based accounting adopted from NPM (Ouda, 2008). The results of this study indicate that the quality of information technology 
does not affect the understanding of accrual-based financial statements. The findings of this study are consistent with the results of research by Usman, Sunandar, \& Farida (2016) and Kusuma (2013) which stating that the quality of information technology served no effect on the implementation of accrual-based financial statements. This finding differed from the results of supra research (2016) assuring that the quality of information technology affected the implementation of accrual-based accounting standards.

The quality of information technology cause does not brought about the understanding of accrual-based financial statements namely the high expense of information technology implementation (Rosiana, Made \& Yogivaria, 2016). This means to improve the quality of information technology requires a high cost. Accordingly, to support devices' interconnection between work units in data transmission. The facr that occurrs Probolinggo government is the absence of interconnection devices between organizations used for data transmission resulting in the fact that maximum information can not be generated from the integrated information system.

\section{CONCLUSION}

The result of the research got the proof that there exists the training influence on the understanding of accrual-based financial statement. This proves that the more responsible government apparatus on their financial reports and financial administration officers to participate in their training would refine their skills as well as ease their job. This research also succeeds in evidencing that work experience gives rise to the understanding of local government apparatus' understanding upon their accrual-based financial statement. That means the more apparatus responsible for their financial statement as well as the more experienced financial administration officers in their task, the better their comprehension on accrual-based financial statement.

This research is not successful in proving the effect of education on the accrual-based financial statement. That signifies the fact that there are still officers misplacement due to the mismatch between their skills and their entrusted jobs resulting in the lack of problem analysis in every SKPD. This research, also, fails to prove the influence of information technology on the understanding of accrual-based financial statement. It signifies that accrual-based financial statement has yet to be generated from integrated information system. 
The whole conclusions of the results of this study are: training and work experience have a positive effect on the understanding of local government officials on accrual-based s financial statements. Education and information technology quality have no effects on the understanding of local government apparatus on accrual-based financial statements. In addition, the more often the training preparartion of accrual-based financial statements in the apparatus and supported by apparatus who have work experience can add their understanding of accrual-based financial statements.

The result of the study proves that training and work experience have an effect on the apparatus understanding on the accrual-based financial statements. This information can be employed by Probolinggo Local Administration in means of the apparatus continuity in making accrual-based financial statement.

\section{REFERENCES}

Alijarde, M. I. (1997). The Usefulness of Financial Reporting in Spanish Local Government. Financial Accountibility \& Management, 13(1), 17-34.

Arikunto, S. (2009). Dasar-Dasar Evaluasi Pendidikan (Edisi Revisi). Jakarta: Bumi Aksara.

Caccia, L., \& Steccolini, I. (2006). Accounting Change in Italian Local Governments: What's Beyond Managerial Fashion? Critical Perspectives on Accounting, 17(2), 154-174.

Cahyadi, D. (2009). Pengaruh Tingkat Pendidikan, Masa Kerja, Pelatihan, dan Posisi di Pemerintahan Terhadap Pemahaman Laporan Keuangan Daerah (Studi Empiris Pada Eksekutif dan Legislatif di Lembaga Pemerintahan Kabupaten Banjarnegara). Tesis, Universitas Diponegoro.

Cavalluzzo, K. S., \& Ittner, C. D. (2004). Implementing Performance Measurement Innovations: Evidence from Government. Accounting, Organizations and Society, 29(3), 243-267.

Christiaens, J. (2001). Converging New Public Management Reforms and Diverging Accounting Practices in Flemish Local Governments. Financial Accountability \& Management, 17(2), 153-170.

Christiaens, J., \& Peteghem, V. V. (2007). Governmental Accounting Reform: Evolution of the Implementation in Flemish Municipalities. Financial Accountability \& Management, 23(4), 375-399.

Christiaens, J., \& Vanhee, C. (2001). Innovations in Governmental Accounting Systems: The Concept of a 'Mega General Ledger' in Belgian Provinces. Working Paper, Faculteit Economie en Bedrijfskunde, Universiteit Gent, Gent. 
Christiaens, J., \& Wielemaker, E. D. (2003). Financial Accounting Reform in Flemish Universities: An Empirical Study of the Implementation. Financial Accountability \& Management, 19(2), 185-204.

Cohen, S., Kaimenaki, E., \& Zorgios, Y. (2007). Assessing IT as a Key Success Factor for Accrual Accounting Implementation in Greek Municipalities. Financial Accountability \& Management, 23(1), 91-111.

Eriva, C. Y., Islahuddin, \& Darwanis. (2013). Pengaruh Tingkat Pendidikan, Pelatihan, Masa Kerja dan Jabatan terhadap Pemahaman Laporan Keuangan Daerah (Studi pada Pemerintah Aceh). Jurnal Akuntansi, 1(2).

Ghozali, I. (2011). Aplikasi Analisis Multivariate dengan Program IBM SPSS 19 -5/E. Semarang: Badan Penerbit Universitas Diponegoro.

Guthrie, J. (1998). Application of Accrual Accounting in the Australian Public Sector-Rhetoric or Reality? Financial Accountability \& Management, 14(1), 1-19.

Halen, H., \& Astuti, D. D. (2013). Pengaruh Tingkat Pemahaman, Pelatihan dan Pendampingan Aparatur Pemerintah Daerah terhadap Penerapan Accrual Basis dalam Pengelolaan Keuangan Daerah di Kabupaten Jember (Studi Kasus pada Dinas Pemerintahan Kabupaten Jember). Jurnal Relasi STIE Mandala Jember, 18, 98-119.

Insani, I. (2009). Pengembangan Kapasitas Sumber Daya Manusia Pemerintah Daerah dalam Rangka Peningkatan Transparansi dan Akuntabilitas Pengelolaan Keuangan Daerah. Jurnal Borneo Administrator, 5(3).

Jantong, A. (2016). Faktor-faktor yang Mempengaruhi Kesiapan Penerapan Standar Akuntansi Pemerintah Berbasis Akrual (Studi Kasus pada Pemerintahan Kabupaten di Manggarai Nusa Tenggara Timur). Tesis, Fakultas Ekonomi dan Bisnis Universitas Brawijaya, Malang.

Kuncoro, M. (2007). Metode Kuantitatif, Teori dan Aplikasi untuk Bisnis dan Ekonomi. Yogyakarta: UPP STIM YKPN.

Koran Madura. (2016). Pemkot Probolinggo Kandas Raih Opini WTP. Dipetik Oktober 3, 2016, dari koranmadura.com: http://www.koranmadura.com/2016/06/29/pemkot-probolinggokandas-raih-opini-wtp/

Krumwiede, K. R. (1998). The Implementation Stages of Activity-Based Costing and The Impact of Contextual and Organizational Factors. Journal of Management Accounting Research, 10, 239-277.

Kusuma, M. I. (2013). Analisis Faktor-Faktor yang Mempengaruhi Tingkat Penerapan Akuntansi Akrual pada Pemerintah. Diponegoro Journal of Accounting, 2(3), 1-14. 
Lelono, K. M. (2014). Tingkat Pemahaman Akuntansi Berbasis Akrual pada Penyusunan Laporan Keuangan Pemerintah Daerah (Studi pada SKPD di Lingkungan Pemerintah Kota Salatiga). Kertas Kerja, Fakultas Ekonomika dan Bisnis Universitas Kristen Satya Wacana, Salatiga.

Malik, N. (2010). Strategi Manajemen Sumberdaya Manusia Berorientasi Investasi Menuju Bangsa yang Berdaya Saing. SALAM, 13(2), 153-161.

Mardiasmo. (2002). Akuntansi Sektor Publik. Yogyakarta: Andi.

Mulyana, B. (2009). Penggunaan Akuntansi Akrual di Negara-Negara Lain: Tren di NegaraNegara Anggota OECD. Dipetik Oktober 16, 2016, dari uns.ac.id: http://sutaryofe.staff.uns.ac.id/files/2011/10/Akuntansi-berbasis-akrual.pdf

Mulyawati, A. (2008). Pengaruh Pendidikan dan Pengalaman Kerja terhadap Motivasi Kerja Karyawan di Bagian Spinning pada PT. Hanil Indonesia Boyolali Tahun 2008. Skripsi, Fakultas Keguruan dan Ilmu Pendidikan Universitas Muhammadiyah Surakartaf.

Nazier, D. M. (2009). Kesiapan SDM Pemerintah Menuju Tata Kelola Keuangan Negara yang Akuntabel dan Transparan. Makalah Seminar Nasional Akuntansi tentang Peningkatan Transparansi dan Akuntabilitas Keuangan Negara dan Daerah Melalui Pengembangan Kapasitas Sumber Daya Manusia Pemerintah Pusat dan Daerah Tanggal 22 Juli 2009. BPK RI.

Ouda, H. A. (2008). Towards a Generic Model for Government Sector Reform: The New Zealand Experience. International Journal Financial Management, 8(2), 78-100.

Parananda, B. H. (2015). Pengaruh Pemahaman Akuntansi, Tingkat Pendidikan, dan Lama Masa Kerja terhadap Penerapan Sistem Akuntansi Pemerintah Daerah (SAPD) pada Kabupaten Ngawi dan Kabupaten Pacitan. Skripsi, Fakultas Ekonomi dan Bisnis Universitas Sebelas Maret, Surakarta.

Pemerintah Republik Indonesia. (2003). Undang-undang Republik Indonesia Nomor 17 Tahun 2003 tentang Keuangan Negara.

Pemerintah Republik Indonesia. (2004). Undang-undang Republik Indonesia Nomor 1 Tahun 2004 tentang Perbendaharaan Negara.

Pemerintah Republik Indonesia. (2004). Undang-undang Republik Indonesia Nomor 32 Tahun 2004 tentang Pemerintahan Daerah.

Pemerintah Republik Indonesia. (2005). Peraturan Pemerintah Republik Indonesia Nomor 58 Tahun 2005 tentang Pengelolaan Keuangan Daerah.

Pemerintah Republik Indonesia. (2010). Peraturan Pemerintah Republik Indonesia Nomor 71 Tahun 2010 tentang Standar Akuntansi Pemerintahan. 
Pollitt, C. (2002). The New Public Management in International Perspective: An Analysis of Impacts and Effects. Dalam K. McLaughlin, S. P. Osborne, \& E. Ferlie (Penyunt.), New Public Management: Current Trends and Future Prospects (hal. 274-292). New York: Routledge.

Pristiani, P., \& Mahmud, A. (2016). Perbedaan Pemahaman Standar Akuntansi Pemerintahan Berbasis Akrual Berdasarkan Demografi Pegawai. Accounting Analysis Journal, 5(1), 18 .

Purnamasari, D. I. (2005). Pengaruh Pengalaman Kerja Terhadap Hubungan Partisipasi dengan Efektifitas Sistem Informasi. Jurnal Riset Akuntansi Keuangan, 1(3).

Raharjo, M. (2008). Dasar-dasar Hermeneutika: Antara Intensionalisme dan Gadamerian. Yogyakarta: Ar-Ruz Media Group.

Rizkianci, A. (2016). Faktor-faktor yang Mempengaruhi Kesiapan Penerapan Standar Akuntansi Pemerintahan Berbasis Akrual pada Badan Pengelolaan Keuangan dan Kekayaan Daerah Provinsi Kepulauan Riau. Skripsi, Fakultas Ekonomi Universitas Maritim Raja Ali Haji, Tanjungpinang.

Robbins, S. P., \& Judge, T. A. (2008). Organizational Behaviour (12th ed.). Jakarta: Salemba Empat.

Rosiana, E., Made, A., \& Yogivaria, D. W. (2016). Pengaruh Kualitas SDM dan Teknologi Informasi terhadap Penerapan SAP Berbasis Akrual PP No 71 Tahun 2010 (Studi Kasus pada SKPD-SKPD Pemerintah Kota Malang). Jurnal Riset Mahasiswa Akuntansi, 4(2).

Selanno, H. (2014). Faktor Internal yang Mempengaruhi Perilaku Organisasi. Populis, 8(2).

Simanjuntak, B. H. (2005). Menyongsong Era Baru Akuntansi Pemerintahan di Indonesia. Jurnal Akuntansi Pemerintah, 1(1).

Simanjuntak, B. H. (2010). Penerapan Akuntansi Berbasis Akrual di Sektor Pemerintahan di Indonesia. Jakarta: Kongres XI Ikatan Akuntan Indonesia.

Supra, D. (2016). Pengaruh Tingkat Pendidikan, Pelatihan, dan Kualitas Teknologi Informasi Terhadap Penerapan Standar Akuntansi Pemerintah Berbasis Akrual pada Pemerintah Kabupaten Musi Banyuasin. Jurnal Accounting Politeknik Sekayu (ACSY), 5(2), 9-23.

Suyanto, M. (2005). Pengantar Teknologi Informasi Untuk Bisnis. Yogyakarta: Penerbit Andi.

Usman, H., \& Akbar, P. S. (2008). Metodologi Penelitian Sosial. Jakarta: PT. Bumi Aksara.

Usman, Sunandar, \& Farida, I. (2016). Analisis Faktor-Faktor yang Mempengaruhi Implementasi Akuntansi Akrual pada Entitas Pemerintah Daerah. Jurnal Akuntansi dan Investasi, 15(2), 101-113. 
Weiss, H. M. (1990). Learning Theory and Industrial and Organizational Psychology. Dalam M. D. Dunnette, \& L. M. Hough (Penyunt.), Handbook of Industrial and Organizational Psychology (2nd ed., Vol. 1). Palo Alto, California: Consulting Psychologists Press, Inc.

Windels, P., \& Christiaens, J. (2008). Management Reform in Flemish Public Centres for Social Welfare: Examining Organisational Change. Local Government Studies, 32(4), 389-411.

Wiraputra et al, W. K. (2014). Pengaruh Pemahaman Standar Akuntansi Pemerintah dan Latar Belakang Pendidikan terhadap Penyusunan dan Penyajian Laporan Keuangan Pemerintah Daerah. (Studi pada Satuan Kerja Perangkat Daerah di Kabupaten Klungkung). Jurnal Ilmiah Mahasiswa, 2(2), 1-10.

Zetra, A. (2009). Strategi Pengembangan Kapasitas SDM Pemerintah Daerah dalam Mewujudkan Transparansi dan Akuntabilitas Pengelolaan Keuangan Daerah. Dipetik Oktober 13, 2016, dari bpk.go.id: http://www.bpk.go.id/assets/files/attachments/2009/07/270609-aidinil-zetra.pdf 